\title{
Sınıf öğretmenlerinin denetim sürecine ilişkin algı ve beklentilerinin metaforlar aracılığı ile belirlenmesi*
}

\author{
Mukadder BOYDAK ÖZAN** \\ Gönül ŞENER ${ }^{* * *}$
}

\section{Özet}

Denetim sürecinin öğretmenin yargılanması olduğu düşüncesi, artık yerini çağdaş denetim yaklaşımının özünü oluşturan öğretmene meslekte yol göstericilik ve yardım düşüncesine bırakmıştır. Denetim sürecinin sağlıklı bir şekilde işlemesi, öğretmenlerin bu sürece ilişkin algılarının ne olduğunun bilinmesiyle mümkün olmaktadır. Bu araştırmada öğretmenlerin denetim sürecine ilişkin algıları ile denetim sürecinden beklentileri metaforlar aracılı̆̆ ile belirlenmeye çalışılmıştır. Bu amaç doğrultusunda öğretmenlerin cinsiyet, eğitim durumu ve mesleki kıdem değişkenlerine göre öne sürmüş oldukları metaforların denetim modelleriyle ilişkisi sorgulanmıştır. Nitel araştırma ile desenlenen bu çalışmada içerik analizi yöntemi kullanılmıştır. Elazığ il merkezinde yer alan okullardan rasgele yöntemle seçilen 60 sınıf öğretmeni örneklem olarak belirlenmiştir. Öğretmenlerin algılarını belirlemeye yönelik olarak hazırlanan "Denetim... gibidir. Çünkü..." ve beklentilerine ilişkin algılarını belirlemeye yönelik olarak "Denetim... gibi olmalıdır. Çünkü...” açık uçlu soruları görüşleri alınmak üzere öğretmenlere sorulmuştur. Öğretmenlerin sorulara vermiş oldukları yanıtlar incelenmiş ve temalar oluşturulmuştur. Sonuç olarak; öğretmenlerin denetim sürecine ilişkin daha çok olumsuz algıya sahip oldukları görülmüştür. Öğretmenler olumsuz algının gerekçesi olarak denetimi açık arama davranışı olarak gördüklerini, ayrıca yaşadıkları baskı ve korkunun da olumsuz algıya neden olduğunu belirtmişlerdir. Denetim sürecini olumlu algılayan öğretmenler; denetimin yapılan çalışmaların değerlendirilmesi konusunda fayda sağladığını bildirmişlerdir. Öğretmenlerin denetim sürecinden beklentilerine ilişkin algılarında ise, denetimin ilkelere uygunluk ve öğretmene yol göstericilik yönü ön plana çıkmıştır.

Anahtar kelimeler: Denetim süreci, algı, beklenti, öğretmen, metafor

\footnotetext{
* Bu çalışmanın ilk hali, 8. Ulusal Eğitim Yönetimi Kongresi’nde (7-8 Kasım 2013, Marmara Üniversitesi) sözlü bildiri olarak sunulmuştur.

** Doç. Dr., Fırat Üniversitesi, Eğitim Fakültesi, mboydak@firat.edu.tr

*** Doktora Öğrencisi, Fırat Üniversitesi, Eğitim Bilimleri Enstitüsü, gonulsener17@hotmail.com
} 


\title{
Examination of supervision-related perceptions and expectations of classroom teachers through metaphors
}

\begin{abstract}
The idea that supervision is the process whereby teacher competency is judged has turned into a notion that it is rather a guidance and assistance for teacher, which underlies the contemporary supervision approach. Smooth functioning of the process of supervision may only be possible if the perceptions of teachers regarding this process are known. In this study, it was aimed to identify the supervision-related perceptions of teachers as well as their expectations from the process of supervision through metaphors. With this purpose in mind, the relation between supervision models and the metaphors put forward by teachers based on such factors as gender, educational background and professional seniority was examined. Content analysis methodology was used in the study which was designed with qualitative research. 60 form teachers randomly selected from schools near Elazığ city center were specified as the sample. In order to get their opinions, the teachers were asked to answer such open-ended questions as "Supervision is like ... Because ..." aimed at identifying their perceptions as well as "Supervision shall be like ... Because ..." for identifying their expectations. The answers were assessed and themes were formed accordingly. Consequently, it was seen that teachers have negative ideas regarding the process of supervision. The reason for this negative perception was that teachers regarded the process of supervision as a search for mistakes; moreover, it was stated by them that the oppression and fear experienced by them also contributed to this negative perception. The teachers who perceived the process of supervision in a positive way stated that supervision provided benefit in terms of assessing the works done. Regarding their expectations from the process of supervision, such aspects of supervision as pertinence to principles and guidance for teachers stood out.
\end{abstract}

Keywords: Process of supervision, perception, expectation, teacher, metaphor

\section{Giriş}

Her karmaşık örgütte olduğu gibi eğitim örgütlerinde de denetim, hem örgütsel hem de yönetsel bir zorunluluktur. Temel amacı, örgütün amaçlarının gerçekleştirilme derecesini saptamak, gerekli önlemleri almak ve süreci geliştirmek olan denetim, örgütsel eylemlerin kabul edilen amaçlar doğrultusunda, belirlenen ilke ve kurallara uygunluğunun anlaşılması sürecidir (Aydin, 2011).

Denetim süreci, yönetimde insan ilişkilerinin öneminin artmasılyla klasik denetim yaklaşımından kurtularak yerini güvene, özdenetime ve demokratik değerlere dayanan, açık aramaktan geliştirmeye doğru bir değişim gösteren çağdaş denetim yaklaşımlarına bırakmaya başlamıştır (Glickman, Gordon ve Ross-Gordon, 2005; Karakuş, 2010; Sullivan ve Glanz, 2000). Birer sosyal sistem olması nedeniyle eğitim örgütlerinin, klasik yönetim anlayışına uygun olarak yönetilmesi ve insanların makine gibi görüldügü bir örgütte, örgüt yapısını oluşturan ilişkilerin, insanların kendilerini gerçekleştirmesine imkân sağlamayan bir yapı oluşturmasına 
neden olmuştur (Kapusuzoğlu, 2008). Bu nedenle klasik denetim anlayışı, örgütlerde etkililiğin sağlanması konusunda yetersiz kalmış ve çağdaş denetim yaklaşımının gerekliliği ortaya çıkmıştır (White, 2006; Memduhoğlu ve Zengin, 2011; İlğan, 2008). Bu gereklilik çağdaş denetim yaklaşımının, sadece kontrol amaçlı değil, aynı zamanda sistemi geliştirmek amacıyla gerçekleştirilen bir süreç olmasından kaynaklanır (Lee, 1998; Gündüz, 2012). Denetim sürecinde öne çıkan modeller; bilimsel, sanatsal, öğretimsel, kliniksel, gelişimsel ve farklılaştırılmış denetim yaklaşımlarıdır (Aydın, 2008). Bu yaklaşımlardan bilimsel denetim klasik yönetim kuramlarının etkisinde kalmış, kontrol ve raporlamaya dayalı, durum saptamayla sınırlı olan klasik bir denetim türüdür. Bu denetim türünde öğretmen ve denetçi arasında ast-üst ilişkileri dışına çıkılmayan bir anlayış hâkimdir (Başar, 2000). Bu modele göre; denetçilerin okuldaki temel işlevi çalışanların bilimsel ilkelere uygun davranıp davranmadıklarını kontrol etmektir. Böylece denetimde asıl vurgulanan husus kabul edilebilir öğretim davranışlarının korunması ve bu davranışların etkili bir biçimde yerine getirilmesinin sağlanmasıdır (Aydın, 2008). Uzun bir döneme yayılmış tekrarlı sınıf gözlemleri yapılmasını gerekli kılan sanatsal yaklaşım, iki profesyonel olarak öğretmen ve denetçi arasında açı bir iletişimin gelişmesine firsat sağlayarak, karşılıklı anlayış ve güven ortamı oluşturmayı sağlar (Aydın, 2008). Bu denetim modeli, öğretmenin, öğretim sürecinde kullandığı dil, beden dili, konuşma, hitap ve anlatım şekli, sınıfı yönlendirme durumu ile ilgili becerilerinden başarılı yönlerinin gelişmesine yardım etmeyi amaçlar (Yllmaz, 2004). Öğretimsel denetim modelinde ise amaç, öğrenciler, öğretmen ve denetmenin işbirliği ile yüksek nitelikli öğrenme ortamları oluşturmak için, eğitim ve öğretim sürecinde özellikle sınıf içi etkinliklerin gözlenmesi yoluyla öğretmene yardımcı olmaktır (Memduhoğlu ve Zengin, 2011). Bu modelde, öğretmen, öğrenci ve denetmen arasında iş birliği ve aktif katılım öne çıar. Öğretimsel denetim, profesyonel bir anlayış ve olumlu bir tutum içinde öğretim sürecinde ortaya çıkan sorunların tanımlanması ve çözümlenmesi yolu ile öğretmenlerin sürekli mesleki gelişimlerine katkıda bulunmayı sağlayan bir yaklaşımdır (Aydın, 2008). Öğretmen ve müfettiş arasındaki yüz yüze ilişki (Goldhammer ve diğerleri, 1980) ve öğretmenin sınıf içindeki gerçek davranışı üzerinde duran kliniksel denetimde, denetmenle öğretmen arasındaki öğretme-öğrenme sürecini geliştirme doğrultusunda yoğun, sürekli ve olgun bir etkileşim kurma önemlidir (Aydın, 1986; Yalçınkaya, 1993). Bu denetim anlayışı, öğretmenlerin bireysel farkındalıklarını, kişisel ve profesyonel yeteneklerini ve dolayısıyla da kendine güven ve yeterlik duygularını arttırarak, onların iş tatmini düzeylerinin artmasına ve örgütsel tükenmişlik düzeylerinin azalmasına sebep olmaktadır (Hyrkas, 2005; McMahon ve Patton, 2000). Diğer bir denetim modeli olan gelişimsel denetimde denetçinin, öğretmenlerin gelişim alanlarındaki ihtiyaçlarına ve bulundukları düzeye en uygun olan denetim yaklaşımını seçmesi ve uygulaması ön plana çıkar. Bu denetim modeli, öğretmenlerin denetçinin yardımıyla, kendi öğretimsel uygulamalarını, iyileştirmesi için gelişim düzeyine ulaşmalarını sağlamayı amaçlar (Grashel, 1997; akt. Karakuş, 2010). Farklılaştırılmış denetim ise, öğretmenlerin farklı gelişim ihtiyaçları ve öğrenme stillerine sahip olmalarından dolayı, denetim sürecinin de öğretmene göre farklılaşması gerektiğini esas alır (Glatthorn, 1984). Öğretmenlerin akademik gelişmişlikleri bakımından farklı seviyelerde oldukları gerçeği göz önünde bulundurulursa modelin her öğretmenin bireysel ihtiyaçlarına daha uygun olacağ 1 gerçeği ortaya çıkar (İlğan, 2008). 
Denetim sürecinin öğretmenin yargılanması olduğu düşüncesi, artık yerini çağdaş denetim yaklaşımının özünü oluşturan öğretmene meslekte yol göstericilik ve yardım düşüncesine bırakmıştır. Denetim sürecinin sağlıklı bir şekilde işlemesi, öğretmenlerin bu sürece ilişkin alg1 ve beklentilerinin ne olduğunun bilinmesiyle mümkün olmaktadır. $\mathrm{Bu}$ araştırmada öğretmenlerin denetim sürecine ilişkin algıları ile denetim sürecinden beklentileri metaforlar aracılığı ile belirlenmeye çalışılmıştır. Bu amaç doğrultusunda öğretmenlerin cinsiyet, eğitim durumu ve mesleki kıdem değişkenlerine göre öne sürmüş oldukları metaforlara ilişkin görüşleri belirlenmeye çalışılmıştır.

\section{Yöntem}

\section{Araştırmanın Modeli}

Sınıf öğretmenlerinin denetim sürecine ilişkin algıları ile bu süreçten beklentilerinin belirlenmeye çalışıldığı bu araştırmada, nitel araştırma yöntemlerinden olgubilim deseni kullanılmıştır. Olgubilim deseni, farkında olduğumuz ancak derinlemesine ve ayrıntılı bir anlayışa sahip olmadığımız olgulara odaklanır. Olgubilim bize tamamen yabancı olmayan ancak tam olarak anlamını kavrayamadığımız olguları araştırmada uygun bir yöntemdir (Yıldırım ve Şimşek, 2011).

\section{Çalışma Grubu}

Araştırmanın evrenini 2012-2013 eğitim-öğretim yılında Elazı̆̆ il merkezinde yer alan öğretmenler oluştururken, örneklemini ise bu okullarda görev yapan 60 sinıf öğretmeni oluşturmaktadır. Örneklem seçiminde küme örnekleme yöntemi kullanılmıştır. Küme örnekleme çalışılması düşünülen evrende doğal olarak oluşmuş veya farklı amaçlarla yapay olarak oluşturulmuş, kendi içinde belirli özellikler açısından benzerlik gösteren değişik grupların olması durumunda kullanılır (Yıldırım ve Şimşek, 2011) Araştırmaya katılan öğretmenlerin demografik özelliklerine göre dağılımları Tablo 1'de verilmiştir.

Tablo |

Öğretmenlerin Demografik Özelliklerine Göre Dağılımları

\begin{tabular}{|c|c|c|c|c|c|c|c|}
\hline Özellik & & f & $\%$ & Özellik & & f & $\%$ \\
\hline \multirow{2}{*}{ Cinsiyet } & Kadın & 20 & 33,3 & \multirow{5}{*}{ Kıdem } & $1-5 \mathrm{yll}$ & 6 & 10 \\
\hline & Erkek & 40 & 66,6 & & 6-10 yıl & 7 & 11,6 \\
\hline \multirow{3}{*}{$\begin{array}{l}\text { Eğitim } \\
\text { Durumu }\end{array}$} & Önlisans & 9 & 15 & & $11-15$ yll & 13 & 21,6 \\
\hline & Lisans & 48 & 80 & & $16-20$ yll & 12 & 20 \\
\hline & Lisansüstü & 3 & 5 & & $21+\ldots$ y1l & 22 & 36,6 \\
\hline
\end{tabular}


Öğretmenlerin kişisel değişkenleri dikkate alındığında; katılımcıların \%33,3’ünü kadın, \%66,6’sını erkek öğretmenler oluştururken, \%15’ini önlisans, \%80'ini lisans, \%5'ini lisansüstü eğitim mezunu öğretmenler oluşturmaktadır. Yine katılımcıların \%10'unu 1-5 yıl, \%11,6'sını 6-10 yıl, \%21,6’sını 11-15 yıl, \%20’sini 16-20 yıl, \%36,6’sını 21 yıl ve üstü kıdeme sahip öğretmenler oluşturmaktadır.

\section{Veri toplama aracı}

Denetim sürecine ilişkin sınıf öğretmenlerinin algılarını belirlemeye yönelik olarak hazırlanan "Denetim... gibidir. Çünkü...” ve bu süreçten beklentilerini belirlemeye yönelik olarak "Denetim... gibi olmalıdır. Çünkü...” açık uçlu soruları görüşleri alınmak üzere öğretmenlere sorulmuştur. Soruların hazırlanmasında, literatürdeki mevcut çalışmalar incelenmiş ve üç uzman görüşü alınmıştır. Sınıf öğretmenlerine, görüşme formları verilerek, gerekli açıklamalar yapılmış bu formları doldurup teslim etmeleri istenmiştir. Doldurulan bu görüşme formları araştırmanın temel veri kaynağ 1 olarak kabul edilmiştir.

\section{Verilerin analizi}

Öğretmen görüşleri dikkate alınarak elde edilen verilerin analizinde nitel araştırmaların çözümlemesinde kullanılan “içerik analizi” yöntemi kullanılmıştır. İçerik analizinde, temelde yapılan işlem, birbirine benzeyen verileri belirli kavramlar ve temalar çerçevesinde bir araya getirmek ve bunu okuyucunun anlayabileceği bir biçimde organize ederek yorumlamaktır. İçerik analizinde temel amaç, toplanan verileri açıklayabilecek kavramlara ve ilişkilere ulaşmaktır. Bu yolla veriler tanımlanmaya, verilerin içinde saklı olabilecek gerçekler ortaya çıkarılmaya çalışılır (Yıldırım ve Şimşek, 2011). Çalışmada ilk olarak öğretmenlerin görüşme formuna vermiş oldukları yanıtlar incelenmiş ve öğretmenlerden toplanan bütün veriler (60 görüşme formu) geçerli kabul edilmiştir. Daha sonra bu veriler üzerinde çözümlemeler yapılmıştır. 60 verinin her birine sırayla sayı numarası verilerek kodlar oluşturulmuştur. Ayrıca her bir soru için bir word belgesi oluşturulmuş ve yanıtlar istatistiksel veri analiz programında analiz edilmiştir. Öğretmenlerin görüşlerinin analizinde, ifadelerin benzerliğine göre gruplandırmalar yapılarak temalar oluşturulmuş ve görüşler uygun temalara yerleştirilerek, bu temaların denetim modelleri ile ilişkisi incelenmiştir. Ayrıca çalışmada öğretmenlerin görüşlerine ilişkin frekans ve yüzde değerleri belirlenmiştir. Her bir temada dikkat çeken katılımcı görüşlerine doğrudan alıntılara yer verilmiştir. Araştırmanın güvenirliliğini ölçmek için, öğretmen görüşlerinden elde edilen yanıtların yerleştirildiği temayı temsil edip etmediğini görebilme amacıyla uzman görüşüne başvurulmuştur. $\mathrm{Bu}$ doğrultuda uzman tarafından incelenmesi istenen soru formlarından elde edilen yanıtlar ile araştırmacı tarafından oluşturulan tema listesi, hiç bir yanıt dışarıda kalmayacak şekilde eşleştirmesi yapılmıştır. Ayrıca araştırmanın güvenilirliğini ölçmek için Miles ve Heberman'ın geliştirdiği Uzlaşma Yüzdesi $(\mathrm{P})=$ Görüş Birliği (Na) / (Görüş Birliği (Na) + Görüş Ayrılığı (Nd)) X 100 formülü kullanılmıştır. Nitel çalışmalarda, uzman ve araştırmacı değerlendirmeleri arasındaki uyumun \%90 ve üzeri olduğu durumlarda güvenirlik sağlanmış olmaktadır (Saban, 2008). Buna göre görüşüne başvurulan uzman sadece 3 ifadeyi araştırmacılardan farklı bir kategoriye yerleştirmiştir. Bu hesaplamanın ardından araştırmanın güvenirliği; $\mathrm{P}=60 /(60+3) \mathrm{X} 100=\% 95$ olarak bulunmuştur. 


\section{Bulgular}

Bu bölümde sınıf öğretmenlerinin açık uçlu sorulara vermiş oldukları yanıtlar incelenmiş, bulgular iki bölüm halinde değerlendirilmiştir. Araştırmanın birinci bölümünü oluşturan “Denetim... gibidir. Çünkü...” metaforuna ilişkin öğretmen algılarına göre; okullarda yaşanan denetim süreci ile ilgili olarak $34(\% 56,6)$ öğretmenin olumsuz, $26(\% 43,3)$ öğretmenin ise olumlu algıya sahip olduğu görülmüştür. Öne sürülen denetim metaforlarına ilişkin oluşturulan ana temalar, ana temalara bağlı kategoriler ve frekans değerleri Şekil 1'de verilmiştir.

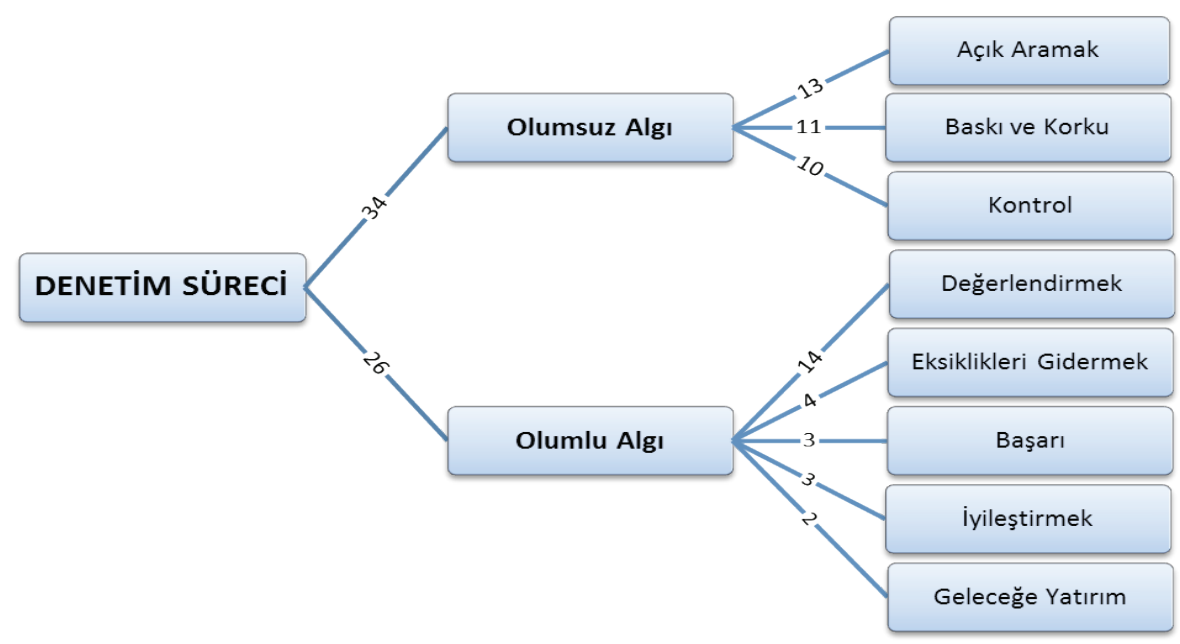

Şekil I. Öğretmenlerin denetim sürecine ilişkin öne sürmüş oldukları metaforlar

Denetim sürecine ilişkin olumsuz algıya sahip öğretmenler, bunun gerekçesi olarak denetimin açık aramak ve kontrol amaçlı yapıldığını, bu durumun ise baskı ve korkuya neden olduğunu ileri sürmüşlerdir. Bu bulgular okullarımızda gerçekleştirilen denetim sürecinde, bilimsel denetim modelinin uygulandığı şeklinde yorumlanabilir. Buna karşın olumlu algıya sahip öğretmenler, denetimin yapılan çalışmaların değerlendirilmesi, eksikliklerin tespit edilmesi ve bu eksikliklerin giderilmesi, istenilen başarı düzeyine ulaşılması, süreç gelişiminin sağlanarak aksayan yönlerin iyileştirmesi ve sistemin varlığını devam ettirmesi için geleceğe yatırım olarak görmüşlerdir. Buna göre, denetimin daha çok çağdaş denetim yaklaşımlarına uygun bir şekilde yapıldığı söylenebilir. Sonuçlar genel olarak incelendiğinde; eğitim denetmenlerinin denetim görevini yürütürken, çoğunlukla bilimsel denetim yaklaşımına uygun bir denetim ortamı oluşturdukları söylenebilir.

Öğretmenlerin cinsiyet, mesleki kıdem ve eğitim durumu değişkenleri dikkate alınarak öne sürmüş oldukları denetim metaforlarının dağılımları Tablo 3’te gösterilmiştir. 
Tablo 3

Öğretmenlerin Denetime Illişkin Olumsuz Algılarının Değişkenlere Göre Dağılımları

\begin{tabular}{|c|c|c|c|c|c|c|c|c|c|c|c|c|c|c|c|c|c|c|c|c|}
\hline \multirow{3}{*}{ Tema } & \multicolumn{4}{|c|}{ Cinsiyet } & \multicolumn{10}{|c|}{ Kıdem } & \multicolumn{6}{|c|}{ Eğitim Durumu } \\
\hline & \multicolumn{2}{|c|}{ Kadın } & \multicolumn{2}{|c|}{ Erkek } & \multicolumn{2}{|c|}{$1-5$ yil } & \multicolumn{2}{|c|}{$6-10$ yil } & \multicolumn{2}{|c|}{$\begin{array}{c}11-15 \\
y 11\end{array}$} & \multicolumn{2}{|c|}{$\begin{array}{c}16-20 \\
y 11\end{array}$} & \multicolumn{2}{|c|}{$21+\ldots \mathrm{y} 1 \mathrm{l}$} & \multicolumn{2}{|c|}{$\begin{array}{c}\text { Ön } \\
\text { lisans }\end{array}$} & \multicolumn{2}{|c|}{ Lisans } & \multicolumn{2}{|c|}{$\begin{array}{l}\text { Lisans- } \\
\text { üstü }\end{array}$} \\
\hline & $\mathrm{f}$ & $\%$ & $\mathrm{f}$ & $\%$ & $\mathrm{f}$ & $\%$ & $\mathrm{f}$ & $\%$ & $\mathrm{f}$ & $\%$ & $\mathrm{f}$ & $\%$ & $\mathrm{f}$ & $\%$ & $\mathrm{f}$ & $\%$ & $\mathrm{f}$ & $\%$ & $\mathrm{f}$ & $\%$ \\
\hline $\begin{array}{l}\text { Açık } \\
\text { Aramak }\end{array}$ & 5 & 45,4 & 8 & 34,7 & 1 & 16,6 & 3 & 42,8 & 2 & 28,5 & 2 & 40,0 & 5 & 55,5 & 1 & 33,3 & 11 & 36,6 & 1 & 100 \\
\hline $\begin{array}{l}\text { Bask1 ve } \\
\text { Korku }\end{array}$ & 5 & 45,4 & 6 & 26,0 & 3 & 50,0 & 2 & 28,5 & 2 & 28,5 & 1 & 20,0 & 3 & 33,3 & 1 & 33,3 & 10 & 33,3 & - & - \\
\hline Kontrol & 1 & 9,2 & 9 & 39,1 & 2 & 33,3 & 2 & 28,5 & 3 & 42,8 & 2 & 40,0 & 1 & 11,1 & 1 & 33,3 & 9 & 30,0 & - & - \\
\hline
\end{tabular}

Denetim sürecine ilişkin olumsuz algıya sahip kadın öğretmenler \%45,4’ü denetimi açık aramak olarak görürken erkeklerde bu oran \%34,7'dir. Denetim sırasında baskı ve korku yaşadığını ileri süren kadın öğretmenler \%45,5 iken, erkek öğretmenler ise \%26'dır. Denetimin kontrol amaçlı yapıldığını ileri süren kadın öğretmenler \%9,2 oranla görüş bildirirken, erkek öğretmenler \%39,1 oranında görüş bildirmişleridir. Bu bulgulara göre kadın öğretmenlerin açık aramak, baskı ve korku temalarına, erkek öğretmenlerin ise kontrol temasında daha sık görüş bildirdikleri görülmektedir. Mesleki kıdemi 1-5 yıl olan öğretmenler (\%50) baskı ve korku temasına daha sık görüş bildirirken, 21 yıl ve üzerinde olan öğretmenler $(\% 55,5)$ açık aramak temasına daha sık görüş bildirmişlerdir. Bu bulgu, öğretmenlerin, mesleğinin ilk yıllarında denetim sırasında baskı ve korkuyu daha sık yaşadıkları, deneyim arttıkça yaşanılan bu baskı ve korkunun azaldığı, emekliliği yaklaşan ya da emeklilik gününü tamamlayan öğretmenlerde ise denetimin bir açık arama davranışı olarak algılandığı şeklinde yorumlanabilir. Eğitim durumu önlisans olan öğretmenler bütün temalara eşit oranda görüş bildirirken, lisans olan öğretmenler $(\% 36,6)$ denetimi en çok açık arama davranışı olarak görmüşlerdir. Bu temayı baskı ve korku $(\% 33,3)$, kontrol (\%30) temaları izlemiştir. Lisansüstü eğitim almış öğretmenlerin tamamı ise denetimi açık arama davranışı olarak değerlendirmişlerdir.

Öğretmenlerin denetim sürecine ilişkin olumsuz görüşleri ile ilgili örnek ifadeler aşağıda verilmiştir:

- Denetim çalışmaları kontrol etmek gibidir. Çünkü her şeye en baştan en sona kadar bakılabilir (Ö16).

- Denetim trafik denetlemesi gibidir. Çünkü istenirse mutlaka bir eksiklik bulunur (Ö21).

- Denetim korku mekanizması gibidir. Çünkü kişi kendi isteğiyle değil korkusundan yapmaktadır (Ö24).

- Denetim diken üzerinde durmak gibidir. Çünkü insan sürekli olarak kontrol altında tutulmaktan izlenmekten hoşlanmaz (Ö25). 
- Denetim polis sorgusu gibidir. Çünkü müfettişler senin ne yaptığına değil ne yapmadığına bakıyor (Ö32).

- Denetim suçluyu bulmak isteyen polis gibidir. Çünkü eksiklikleri nasıl bulurum, öğretmeni nasıl köşeye sıkıştırırım düşüncesi vardır (Ö41).

- Denetim hırsızı bulmak gibidir. Çünkü gelen denetçi sadece eksiklikleri söyler. Çoğu zaman kalıplaşmış puanlama kullanılır. Amaç denetleme değil adet yerini bulsundur (Ö51).

Öğretmenlerin cinsiyet, mesleki kıdem ve eğitim durumu değişkenleri dikkate alınarak öne sürmüş oldukları denetim metaforlarının dağılımları Tablo 4’te gösterilmiştir.

Tablo 4

Öğretmenlerin Denetime Illişkin Olumlu Algılarının Değişkenlere Göre Dağılımları

\begin{tabular}{|c|c|c|c|c|c|c|c|c|c|c|c|c|c|c|c|c|c|c|c|c|}
\hline \multirow{3}{*}{ Tema } & \multicolumn{4}{|c|}{ Cinsiyet } & \multicolumn{10}{|c|}{ Kidem } & \multicolumn{6}{|c|}{ Eğitim Durumu } \\
\hline & \multicolumn{2}{|c|}{ Kadın } & \multicolumn{2}{|c|}{ Erkek } & \multicolumn{2}{|c|}{$1-5 \mathrm{yll}$} & \multicolumn{2}{|c|}{ 6-10 yıl } & \multicolumn{2}{|c|}{$\begin{array}{c}11-15 \\
y 11\end{array}$} & \multicolumn{2}{|c|}{$\begin{array}{c}16-20 \\
y 11\end{array}$} & \multicolumn{2}{|c|}{$\begin{array}{c}21+\ldots \\
\text { yll }\end{array}$} & \multicolumn{2}{|c|}{ Önlisans } & \multicolumn{2}{|c|}{ Lisans } & \multicolumn{2}{|c|}{$\begin{array}{l}\text { Lisan- } \\
\text { süstü }\end{array}$} \\
\hline & $\mathrm{f}$ & $\%$ & $\mathrm{f}$ & $\%$ & $\mathrm{f}$ & $\%$ & $\mathrm{f}$ & $\%$ & $\mathrm{f}$ & $\%$ & $\mathrm{f}$ & $\%$ & $f$ & $\%$ & $\mathrm{f}$ & $\%$ & $\mathrm{f}$ & $\%$ & $\mathrm{f}$ & $\%$ \\
\hline $\begin{array}{l}\text { Değerlen- } \\
\text { dirmek }\end{array}$ & 5 & 55,5 & 9 & 52,9 & - & - & - & - & 2 & 33,3 & 6 & 100 & 6 & 46,1 & 3 & 50 & 11 & 42,3 & - & - \\
\hline $\begin{array}{l}\text { Eksiklikleri } \\
\text { Gidermek }\end{array}$ & 1 & 11,1 & 3 & 17,6 & - & - & - & - & 1 & 16,6 & - & - & 3 & 23,0 & 1 & 16,6 & 3 & 11,5 & - & - \\
\hline Başarı & 2 & 22,2 & 1 & 5,8 & - & - & - & - & 2 & 33,3 & - & - & 1 & 7,6 & 1 & 16,6 & 2 & 7,6 & - & - \\
\hline İyileştirmek & 1 & 11,1 & 2 & 11,7 & - & - & 1 & 100 & 1 & 16,6 & - & - & 1 & 7,6 & - & - & 1 & 3,8 & 100 & 7,6 \\
\hline $\begin{array}{l}\text { Geleceğe } \\
\text { Yatırım }\end{array}$ & - & - & 2 & 11,7 & - & - & - & - & - & - & - & - & 2 & 15,3 & 1 & 16,6 & 1 & 3,8 & - & - \\
\hline
\end{tabular}

Denetim sürecine ilişkin olumlu algılara sahip kadın $(\% 55,5)$ ve erkek $(\% 52,9)$ öğretmenler, denetimin yapılan çalışmaların değerlendirilmesi konusunda fayda sağladığını ileri sürmüşlerdir. Kadın öğretmenlerde bu temayı başarı $(\% 22,2)$, eksiklikleri gidermek $(\% 11,1)$ ve iyileştirmek $(\% 11,1)$ temaları izlerken, erkek öğretmenlerde ise eksiklikleri gidermek $(\% 17,6)$, iyileştirmek $(\% 11,7)$ ve geleceğe yatırım $(\% 11,7)$ temaları izlemiştir. Mesleki kıdemi 1-5 yıl olan öğretmenler denetim sürecine ilişkin olumlu görüş bildirmezken, 21 yıl ve üzeri kıdeme sahip öğretmenler değerlendirmek $(\% 46,1)$ temasına ilişkin daha sık görüş bildirmişlerdir. Mesleki kıdemi 1-5 yıl olan öğretmenlerin denetim sürecine ilişkin olumlu görüş bildirmediği dikkat çekicidir. Bu bulgu mesleğinin ilk yıllarındaki öğretmenlerin daha çok denetim sürecine maruz kaldıkları, deneyimsiz oluşları nedeni ile denetmenlerden eleştiri aldıkları ve bu nedenle de denetime ilişkin olumlu 
algıya sahip olmadıkları şeklinde yorumlanabilir. Eğitim durumu önlisans olan öğretmenler ile lisans olan öğretmenler değerlendirmek temasına ilişkin daha sık görüş bildirirken, eğitim durumu lisansüstü olan öğretmenler ise iyileştirmek temasına daha sık görüş bildirmişlerdir. Lisansüstü eğitime sahip öğretmenlerin görüşlerindeki bu farklılık öğretmenlerin denetimi bir geliştirme süreci olarak algılamasından kaynaklanmaktadır.

Öğretmenlerin denetim sürecine ilişkin olumlu görüşleri ile ilgili örnek ifadeler aşağıda verilmiştir:

- Denetim eksiklikleri giderme gibidir. Çünkü denetimle eksikliklerinizin farkına varırsinız (Ö7).

- Denetim doktorluk gibidir. Çünkü doktor hastalığı bulup iyileşmeyi sağlar (Ö33).

- Denetim mesleki anlamda kendini aynada görmek gibidir. Çünkü sizin dışındaki gerçeklerle yüzyüze gelmektir (Ö37).

- Denetim sürece farklı bir gözle bakmak gibidir. Çünkü öğretmenin farkında olmadığı ve göremediği noktalara başka gözle bakma ve görme değerlendirme fırsatı sağlar (Ö47).

- Denetim yapılan çalışamaların ölçümü gibidir. Çünkü çalışma amacına ulaşmış mı ulaşmamış mı sorusuna cevaptır (Ö58).

Araştırmanın ikinci bölümünde ise öğretmenlere "Denetim ... gibi olmalıdır. Çünkü ...” açık uçlu sorusu sorulmuş ve böylece öğretmenlerin denetim sürecine ilişkin beklentileri metaforlar aracılığı ile belirlenmeye çalışılmıştır. Bu metaforlara ilişkin oluşturulan ana temalar, ana temalara bağlı kategoriler ve frekans değerleri Şekil 2'de verilmiştir.

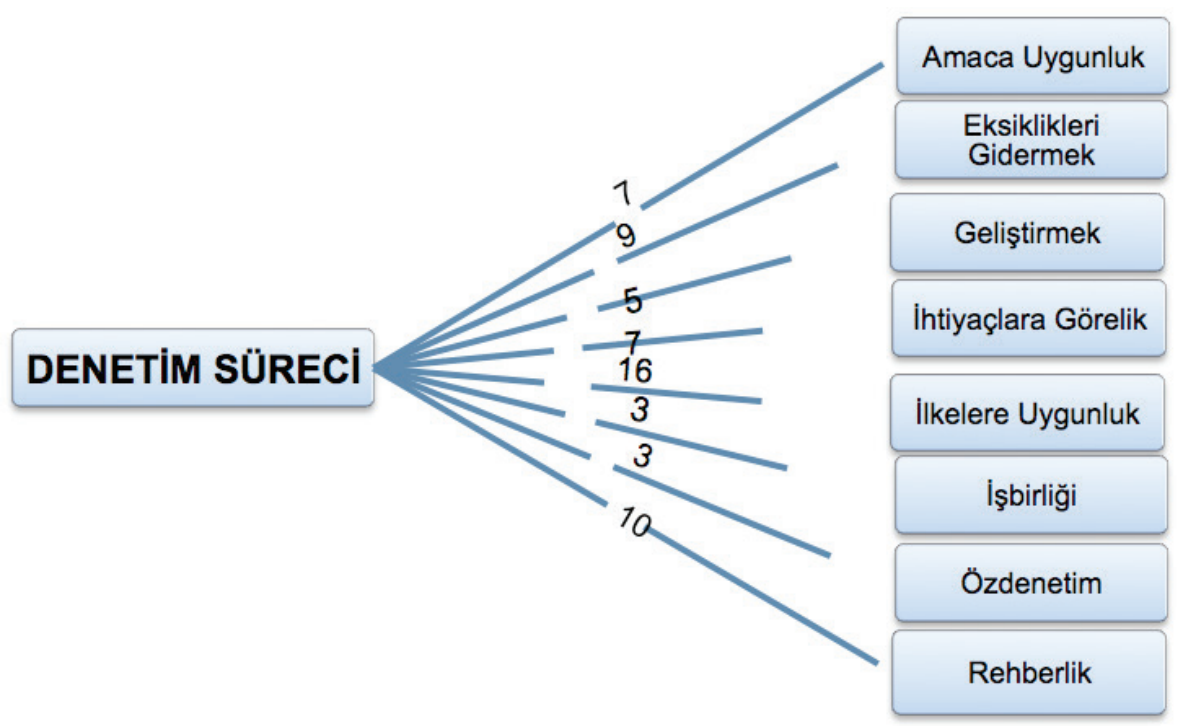

Şekil 2. Öğretmenlerin denetim sürecinden beklentilerine ilişkin öne sürmüş oldukları metaforlar 
Öğretmenler denetim sürecinin daha çok tarafsızlık, şeffaflık, adalet gibi ilkelere uygun $(\% 26,6)$ bir şekilde yapılmasının gerekliliğini ileri sürmüşlerdir. Bu temayı rehberlik $(\% 16,6)$, eksiklikleri gidermek (\%15), amaca uygunluk $(\% 11,6)$, ihtiyaçlara görelik $(\% 11,6)$ ve geliştirmek $(\% 8,3)$ temaları izlemiştir. Öğretmenlerin en az görüş bildirdikleri temalar ise işbirliği (\%5) ve özdenetim (\%5) temalarıdır. Bu bulgulara göre; öğretmenlerin denetim sürecinden beklentileri çağdaş denetim modellerine uygun olarak yürütülen denetimdir.

Öğretmenlerin cinsiyet, mesleki kıdem ve eğitim durumu değişkenleri dikkate alınarak öne sürmüş oldukları denetim metaforlarının dağılımları Tablo 5 ’te gösterilmiştir.

Tablo 5

Öğretmenlerin Denetim Sürecinden Beklentilerine Iliş̧kin Algılarının Değişkenlere Göre Dă̆ılımları

\begin{tabular}{|c|c|c|c|c|c|c|c|c|c|c|c|c|c|c|c|c|c|c|c|c|}
\hline \multirow{3}{*}{ Tema } & \multicolumn{4}{|c|}{ Cinsiyet } & \multicolumn{10}{|c|}{ Kıdem } & \multicolumn{6}{|c|}{ Eğitim Durumu } \\
\hline & \multicolumn{2}{|c|}{ Kadın } & \multicolumn{2}{|c|}{ Erkek } & \multicolumn{2}{|c|}{$1-5$ yll } & \multicolumn{2}{|c|}{$6-10$ yil } & \multicolumn{2}{|c|}{$11-15$ yll } & \multicolumn{2}{|c|}{$16-20$ yll } & \multicolumn{2}{|c|}{$21+\ldots y 1$} & \multicolumn{2}{|c|}{ Önlisans } & \multicolumn{2}{|c|}{ Lisans } & \multicolumn{2}{|c|}{ Lisansüstü } \\
\hline & $\mathrm{f}$ & $\%$ & $\mathrm{f}$ & $\%$ & $\mathrm{f}$ & $\%$ & f & $\%$ & $\mathrm{f}$ & $\%$ & $\mathrm{f}$ & $\%$ & $\mathrm{f}$ & $\%$ & $\mathrm{f}$ & $\%$ & $\mathrm{f}$ & $\%$ & $\mathrm{f}$ & $\%$ \\
\hline $\begin{array}{l}\text { Amaca } \\
\text { Uygunluk }\end{array}$ & 2 & 8,0 & 5 & 17,2 & 1 & 13,6 & - & - & 1 & 7,6 & 2 & 18,1 & 3 & 13,6 & 2 & 25,0 & 5 & 10,4 & - & - \\
\hline $\begin{array}{l}\text { Eksiklikleri } \\
\text { Gidermek }\end{array}$ & 1 & 4,0 & 2 & 6,8 & - & - & 3 & 37,5 & - & - & 1 & 9,0 & 5 & 22,7 & 1 & 12,5 & 6 & 12,5 & 1 & 33,3 \\
\hline Geliştirmek & 1 & 4,0 & 4 & 13,7 & - & - & 1 & 12,5 & 2 & 15,3 & - & - & 2 & 9,0 & - & - & 5 & 10,4 & - & - \\
\hline $\begin{array}{l}\text { İhtiyaçlara } \\
\text { Görelik }\end{array}$ & 4 & 16,0 & 3 & 10,3 & - & - & 1 & 12,5 & 3 & 23,0 & - & - & 3 & 13,6 & 1 & 12,5 & 5 & 10,4 & 1 & 33,3 \\
\hline $\begin{array}{l}\text { İlkelere } \\
\text { Uygunluk }\end{array}$ & 6 & 24,0 & 10 & 34,4 & 2 & 33,3 & - & - & 4 & 30,7 & 4 & 36,3 & 6 & 27,2 & 3 & 37,5 & 12 & 25,0 & 1 & 33,3 \\
\hline İş birliği & 3 & 12,0 & - & - & - & - & - & - & 1 & 7,6 & 2 & 18,1 & - & - & - & - & 3 & 6,25 & - & - \\
\hline Özdenetim & 2 & 8,0 & 1 & 3,4 & 2 & 33,3 & - & - & 1 & 7,6 & - & - & - & - & - & - & 3 & 6,25 & - & - \\
\hline Rehberlik & 6 & 24,0 & 4 & 13,7 & 1 & 16,6 & 3 & 37,5 & 1 & 7,6 & 2 & 18,1 & 3 & 13,6 & 1 & 12,5 & 9 & 18,7 & - & - \\
\hline
\end{tabular}

Öğretmenlerin denetim sürecine ilişkin beklentilerini belirlemeye yönelik yapılan analizler sonucunda; kadın öğretmenler \%24 oranında, erkek öğretmenler ise \%34,4 oranında denetimin ilkelere uygun bir şekilde yapılması gerektiğini ileri sürmüşlerdir. Mesleki kıdemi 1-5 yıl olan öğretmenler ilkelere uygunluk $(\% 33,3)$ ve özdenetim $(\% 33,3)$ temalarına daha sık görüş bildirirken, mesleki kıdemi 21 yıl ve üzerinde olan öğretmenler ilkelere uygunluk $(\% 22,7)$ ve eksiklikleri gidermek (\%22,7), temalarına daha sık görüş bildirmiştir. Eğitim durumu önlisans $(\% 37,5)$, lisans $(\% 25)$ ve lisansüstü $(\% 33,3)$ olan öğretmenler de ilkelere uygunluk temasına 
daha sık görüş bildirmişlerdir. Bu bulgular ışığında, öğretmenler denetimin daha çok şeffaflık, tarafsızlık ve adalet gibi ilkelere uygun bir şekilde yapılmasını denetimin rehberlik yönünün ön plana çıkmasını bekledikleri şeklinde yorumlanabilir.

Öğretmenlerin denetim sürecinden beklentilerine ilişkin görüşleri ile ilgili örnek ifadeler aşağıda verilmişsir:

- Denetim eğitsel ve öğretimsel becerilerin toplamı gibi olmalıdır (Ö9).

- Denetim objektif ve tarafsız olmalıdır. Çünkü tarafsız olmayan bir denetimle denetim sağlanamaz (Ö13).

- Denetim daha çok aksayan yönleri tamamlayıcı gibi olmalıdır. Çünkü denetim yapılan işlerin elden geçirilmesidir (Ö16).

- Denetim yelpaze gibi olmalıdır. Çünkü öğrenciler çeşitlidir. Ortaya çıkan ürünler de çeşitlidir. Onları bu geniş yelpazede değerlendiren biz öğretmenler gibi denetiminde bu geniş yelpazeyi görmesi gerekir (Ö27).

- Denetim her zaman ama esnek olmalıdır. Çünkü daimi denetim başarının anahtarıdır (Ö28).

- Denetim cam gibi olmalıdır. Çünkü her şey görünmelidir (Ö31).

- Denetim bireyin kılavuzu gibi olmalıdır. Çünkü yetersiz kaldığı durumlarda sana yol göstermelidir (Ö30).

\section{Tartışma}

Araştırmanın birinci bölümünde, öğretmenlerin denetim sürecine ilişkin algıları incelendiğinde; bu süreci olumlu algılayan öğretmenlerin yanında olumsuz algıya sahip öğretmenlerin de olduğu görülmüştür. Olumlu algıya sahip öğretmenler; denetimin yapılan çalışmaların değerlendirilmesi, eksikliklerin tespit edilmesi ve bu eksikliklerin giderilmesi, istenilen başarı düzeyine ulaşılması, süreç gelişiminin sağlanarak aksayan yönlerin iyileştirmesi ve sistemin varlığını devam ettirmesi için geleceğe yatırım olduğunu belirtmişlerdir. Buna karşın olumsuz algıya sahip öğretmenler; denetimin açık aramak ve kontrol amaçlı yapıldığını, bu durumun ise baskı ve korkuya neden olduğunu ileri sürmüşlerdir. Denetim sürecine ilişkin olumsuz algıya sahip öğretmen görüşlerinin daha fazla olması dikkat çekicidir. Bu sonuç, okullarda yürütülen denetimlerde çoğunlukla bilimsel denetim yaklaşımının etkili olduğunu göstermektedir. Yapılan çeşitli araştırmalar da denetimin, her düzeydeki personelde stres ve moral bozukluğu oluşturduğu, okul örgütünde negatif etkilere yol açabildiğini, denetimin sistemdeki aksaklıkları belirlemeye ve eğitimin niteliğine katkısının sınırlı olduğununu göstermiştir (Jeffrey ve Woods, 1996; Ouston ve diğerleri, 1997; Özmen ve Özdemir, 2012; Perryman, 2007; Tunç ve diğerleri, 2013; Yüksel, 2011).

Değişkenler açısından incelendiğinde; denetim sürecine ilişkin olumlu algılara sahip hem 
kadın hem de erkek öğretmenler, denetimin yapılan çalışmaları değerlendirme konusunda fayda sağladığını ileri sürmüşlerdir. Kadın öğretmenlerde bu temayı başarı, eksiklikleri gidermek ve iyileştirmek temaları izlerken, erkek öğretmenlerde ise eksiklikleri gidermek, iyileştirmek ve geleceğe yatırım temaları izlemiştir. Mesleki kıdemi 1-5 yll olan öğretmenler denetim sürecine ilişkin olumlu görüş bildirmezken, 21 yıl ve üzerinde kıdeme sahip öğretmenler değerlendirmek temasına daha sık görüş bildirmişlerdir. Mesleki kıdemi 1-5 yıl olan öğretmenlerin denetim sürecine ilişkin olumlu görüş bildirmemesinin nedeni, mesleğinin ilk ylllarında öğretmenlerin daha çok denetim sürecine maruz kaldıkları, deneyimsiz oluşları nedeni ile denetmenlerden eleştiri aldıkları ve bu nedenle de denetime ilişkin olumlu algıya sahip olmadıkları şeklinde yorumlanabilir. Eğitim durumu değişkeninde ise önlisans mezunu öğretmenler ile lisans mezunu öğretmenler değerlendirmek temasına daha sık görüş bildirirken, eğitim durumu lisansüstü olan öğretmenler iyileştirmek temasına daha sık görüş bildirmişlerdir. Lisansüstü eğitime sahip öğretmenlerin görüşlerindeki bu farklılık öğretmenlerin denetimi bir geliştirme süreci olarak algılamasından kaynaklı olabilir.

Denetim sürecine ilişkin olumsuz algıya sahip kadın öğretmenlerin açı aramak, baskı ve korku temalarında, erkek öğretmenlerin ise kontrol temasında daha sık görüş bildirdikleri görülmüştür. Bu sonuca göre kadın öğretmenlerin denetim sürecinde daha fazla tedirginlik yaşadığı söylenebilir. Mesleki kıdeme göre çalışma süresi 1-5 yıl olan öğretmenler baskı ve korku temasına daha sık görüş bildirirken 21 yıl ve üzerinde olan öğretmenler ise açık aramak temasına daha sık görüş bildirmişlerdir. Bu bulgu, öğretmenlerin, mesleğinin ilk yıllarında denetim sırasında baskı ve korkuyu daha sık yaşadıkları, deneyim arttıkça yaşanılan bu baskı ve korkunun azaldığı, emekliliği yaklaşan ya da emeklilik süresini tamamlayan öğretmenlerde ise denetimin bir açık arama davranışı olma bilincinin oluştuğu şeklinde yorumlanabilir. Eğitim durumu değişkenine göre, önlisans mezunu öğretmenler bütün temalara eşit oranda görüş bildirirken, lisans mezunu öğretmenler denetimi en çok açı arama davranışı olarak görmüşlerdir. Bu temayı baskı ve korku, kontrol temaları izlemiştir. Lisansüstü eğitim almış öğretmenlerin tamamı ise denetimi açı arama davranışı olarak değerlendirmiştir.

Araştırmanın ikinci bölümünde, öğretmenlerin denetim sürecine ilişkin beklentileri incelendiğinde; öğretmenler denetim sürecinin daha çok ilkelere uygun bir şekilde yapılmasının gerekliliğini ileri sürmüşlerdir. Bu temayı rehberlik, eksiklikleri gidermek, amaca uygunluk, ihtiyaçlara görelik ve geliştirmek temaları izlemiştir. Öğretmen görüşlerinde yer alan bu beklentiler denetim sistemindeki eksiklikleri göstermektedir. Öte yandan öğretmenlerin denetim sürecindeki beklentilerinin çağdaş denetim modellerine uygun olduğunu söylemek mümkündür. Memduhoğlu (2012) yaptı̆̆ı çalışmada, denetimin gereksinim odaklı yapılması gerektiğini vurgularken, Gündüz (2012) denetimin, öğrenme-öğretme ortamının analizi, ortamın değerlendirilmesi ve sürecin geliştirilmesi gibi işlevleri üstlenmesi gerektiğini vurgulamıştır. Özellikle denetmenlerin rehberlik rollerini yerine getirmediğine ilişkin olarak benzer sonuçlar; Altun ve Memişoğlu (2008), Britton ve diğerleri (2002), Can (2004), Ekinci, Karakuş (2011), Özdayı ve Özcan (2002)'in çalışmalarında da görülmüştür.

Değişkenler açısından değerlendirildiğinde; hem kadın hem de erkek öğretmenler denetimin 
ilkelere uygun bir şekilde yapılması gerektiğini ileri sürmüşlerdir. Benzer sonuçlar mesleki kıdem değişkeninde de gözlenmiştir. Mesleki kıdemi 1-5 yıl olan öğretmenler ilkelere uygunluk ve özdenetim temalarına daha sık görüş bildirirken, mesleki kıdemi 21 yıl ve üzerinde olan öğretmenler ilkelere uygunluk ve eksiklikleri gidermek temalarına daha sık görüş bildirmiştir. Eğitim durumu önlisans, lisans ve lisansüstü olan öğretmenlerin de ilkelere uygunluk temasina daha sık görüş bildirdikleri görülmüştür.

Araştırma bulgularına dayalı olarak aşağıdaki öneriler geliştirilebilir:

- Eğitim örgütlerinde öğretim sürecini geliştirmekten uzak olan bilimsel denetim yaklaşımının yerine, bu sürece katkı sağlayacak çağdaş denetim yaklaşımları benimsenmelidir.

- Denetim sürecinde, denetimin bir açık arama davranışı olma bilincinden öte öğretmenlere yol göstericilik yönünün ağır bastığı denetim anlayışı benimsenmelidir.

- Öğretmenlerin denetimlerde yaşadıkları baskı ve korkuyu ortadan kaldırmak ve denetmenlerle olan etkileşimlerini arttırmak için sosyal ortamlar oluşturulmalıdır.

- Denetmenlere insan ilişkileri ve iletişim becerileri konusunda kişisel ve mesleki gelişimlerine katkı sağlayacak hizmet-içi seminerler verilmelidir. 


\section{Kaynaklar}

Altun, S. A., \& Memişoğlu, S. P. (2008). Performans değerlendirmesine ilişkin öğretmen, yönetici ve müfettiş görüşleri. Kuram ve Uygulamada Eğitim Yönetimi, 53, 7-24.

Aydın, İ. (2008). Öğretimde denetim (2. Baskı). Ankara: Pegem Akademi Yayınları.

Aydın, M. (1986). Çağdaş eğitim denetimi. Ankara: Eğitim Araştırma Yayın Danışmanlık.

Aydın, M. (2011). Çă̆daş eğitim denetimi (6. Baskı). Ankara: Hatipoğlu Yayınevi.

Başar, H. (2000). Eğitim denetçisi. Ankara: PegemA Yayıncılık.

Britton, P. J., Goodman, J. M. \& Rak, C. F. (2002). Presenting workshops on supervision: a didacticeperiential format, Counselor Education \& Supervision, 42(1), 31-39.

Can, N. (2004). İlköğretim öğretmenlerinin denetimi ve sorunları. Milli Eğitim Dergisi, 164, 112-122.

Ekinci, A., \& Karakuş, M. (2011). İlköğretim okullarında müfettişlerce yapılan rehberlik ve denetim çalışmalarının işlevselliği. Kuram ve Uygulamada Eğitim Bilimleri, 11(4), 1849-1867.

Erdem, A. R. (2006). Öğretimin denetiminde yeni bakış açısı: "sürekli geliştirme” temeline dayalı öğretimin denetimi, Selçuk Üniversitesi Sosyal Bilimler Enstitüsü Dergisi, 16, 275-294.

Glatthorn, A. A. (1997). Differentiated supervision. (2nd Edition). Virginia: ASCD.

Glickman, C. D., Gordon, S. P., \& Ro-Gordon, J. M. (2005). The basic guide to supervision and teaching leadership. Boston: Allyn-Bacon.

Goldhammer, R., Anderson, R. H., \& Krajewski, R. (1980). Clinical supervision: special methods for the supervision of teachers. (2nd Ed.) USA: Holt, Rinehart and Winston Inc.

Gündüz, Y. (2012). Eğitim örgütlerinde denetimin gerekliliği: kuramsal bir çalışma, Dumlupınar Üniversitesi Sosyal Bilimler Dergisi, 34.

Hyrkas, K. (2005). Clinical supervision, burnout and job satisfaction among mental health and psychiatric nurses in Finland, Issues in Mental Health Nursing, 26(5), 531-556.

İlğan, A. (2008). İlköğretim müfettişleri ve öğretmenlerinin farklılaştırılmış denetim modelini benimseme ve uygulanabilir bulma düzeyleri, Kuram ve Uygulamada Eğitim Yönetimi, 55, 389-422.

Jeffrey, B., \& Woods, P. (1996). Feeling deprofessionalised: the social construction of emotions during an OFSTED inspection. Cambridge Journal of Education, 26(3), 325-343.

Kapusuzoğlu, Ş. (2008). Okula dayalı yönetimde denetim sisteminin işlevselliği ve katkısının değerlendirilmesi, Abant İzzet Baysal Üniversitesi Sosyal Bilimler Enstitüsü Dergisi, 1(16),143-155.

Karakuş, M. (2010). Çağdaş denetim yaklaşımları. Firat Üniversitesi Sosyal Bilimler Dergisi, 20(2), 181-200.

Lee, J. (1998). Improving student learning. İstanbul: Kalder Yayınları.

Mcmahon, M., \& Patton, W. (2000). Conversations on clinical supervision: benefits perceived by school counsellors, British Journal of Guidance \& Counselling, 28(3), 339-351.

Memduhoğlu, H. B. (2012). Öğretmen, yönetici, denetmen ve öğretim üyelerinin görüşlerine göre Türkiye’de eğitim denetimi sorunsalı, Kuram ve Uygulamada Eğitim Bilimleri, 12(1), 135-156.

Memduhoğlu, H. B., \& Zengin, M. (2011). Çağdaş eğitim denetimi modeli olarak öğretimsel denetimin türk eğitim sisteminde uygulanabilirliği, Kuramsal Eğitim Bilim Dergisi, 5(1), 131-142.

Ouston, J., Fidler, B. \& Early, P. (1997). What do schools do after OFSTED school inspection-or before, School Leadership and Management: Formerly School Organisation, 17(1), 95-104.

Özdayı, N., \& Özcan, Ş. (2002). Teftiş sürecindeki geri bildirimlere göre teftişin öğrenen örgüt kültürüne katkılarının öğretmen görüşleriyle değerlendirilmesi. Öğrenme ve Öğretme Sempozyumunda Sunulan Bildiri, Marmara Üniversitesi, Atatürk Eğitim Fakültesi, İstanbul. 
Özmen, F. \& Özdemir, T. Y. (2012). Anlatılan öykülere dayalı olarak, denetçilerin denetlenenlerle yüz yüze iletişimlerinde yaşadıkları sorunlar, Milli Eğitim Dergisi, 195, 43-66.

Perryman, J. (2007). Inspection and emotion, Cambridge Journal of Education, 37(2), 173-190.

Sullivan, S., \& Glanz, J. (2000). Alternatives approaches to supervision: case from the field, Journal of Curriculum and Supervision, 15(3), 212-235.

Tunç, B., İnandı, Y., Öksüz, F. \& Çal, S. (2013). Eğitimde çok bileşenli değerlendirme: velilerin okul yöneticilerinin performans değerlendirmesine katılımı, Trakya Üniversitesi Eğitim Fakültesi Dergisi, 3(1), 90-99.

White, D. (2006). Cognitive coaching when used alongside proven management techniques can increase in technical organisations. Jossey Bass, 1-6.

Yalçınkaya, M. (1993). Klinik teftiş farklı bir model mi? Ankara Üniversitesi Eğitim Bilimleri Fakültesi Dergisi, 26(2), 379-386.

Yıldırım, A., \& Şimşek, H. (2011). Sosyal bilimlerde nitel araştırma yöntemleri. (8. Baskı) Ankara: Seçkin Yayıncilik.

Yllmaz, K. (2004). Sanatsal denetim, Kuramdan Uygulamaya Eğitim Yönetimi, 38, 292-311.

Yüksel, G. (2011). Teftiş uygulamalarının öğretmenlerde yarattığı stres düzeyinin incelenmesi, Uludağ Üniversitesi Eğitim Fakültesi Dergisi, 24(2), 367-388. 
